\title{
A PARTIAL ALBINO MEADOW VOLE
}

by Larry Morgotch, 15A Bradbrooke Apts., Yorkton

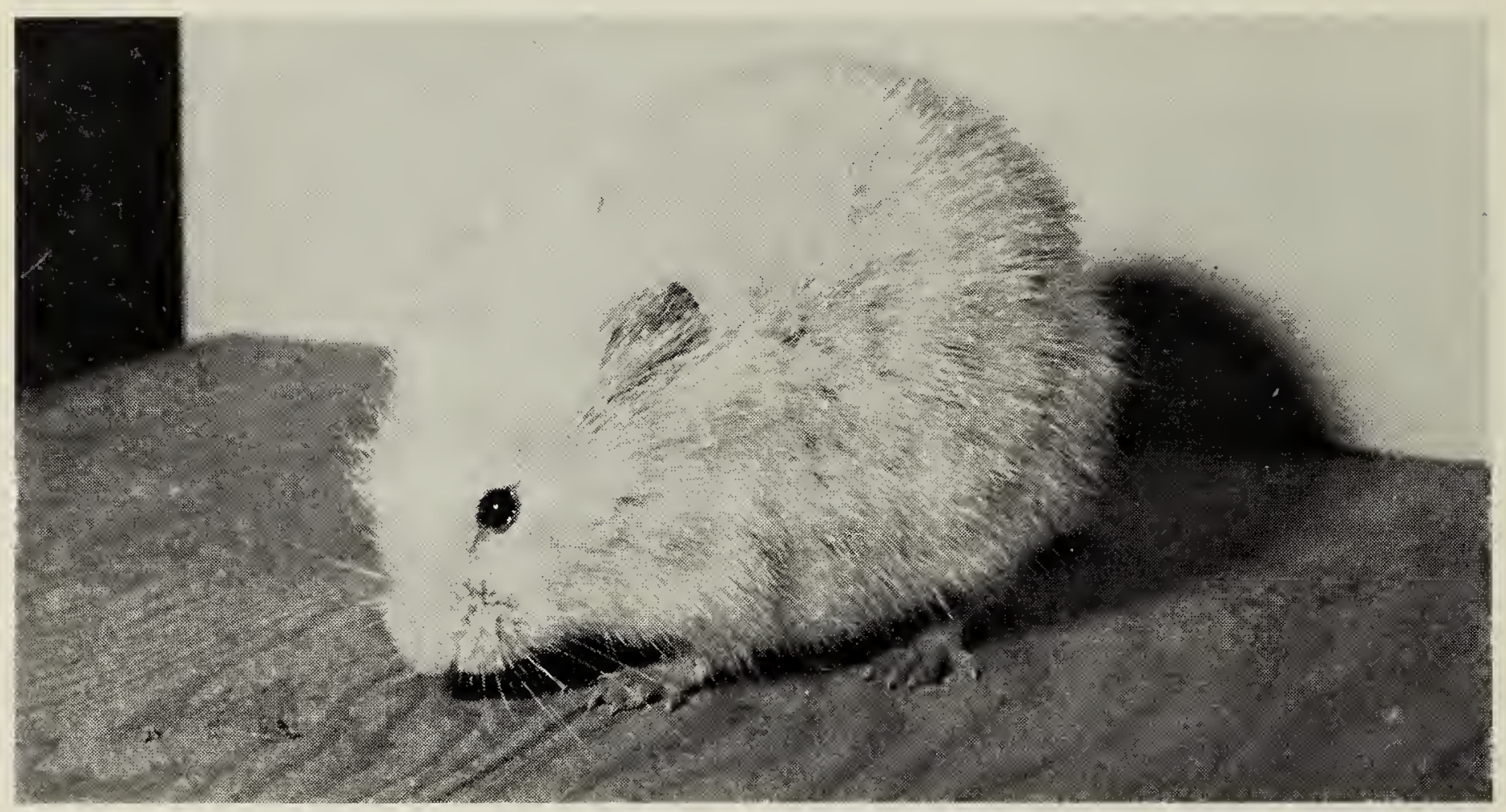

Partial albino Meadow Vole

Photo by Larry Morgotch

Stewart Pinder, a farmer near Springside, Saskatchewan, captured a white mouse on October 21, 1966. He found it when he was picking up bales on his farm. The mouse was given to Les Merriman in Springside and at time of writing (October 31) it is still in a healthy and lively condition.

When I heard of this mouse I drove to Springside to see it and to photograph it. It has all of the characteristics of a Meadow Vole, Microtus pennsylvanicus (Ord). Its body is $3 \frac{1 / 2}{2}$ long; its tail is $1 \frac{1 / 2}{}$ " long. It has five toes on its hind feet but it appears to have only four toes on its front feet for the thumb is very much reduced. The right eye had been injured and was closed but the left eye has a black pupil and the iris is sky blue. At first glance the animal appears white but the fur on the back has a slight tan colour. Because the eyes are not pink and the fur is not pure white this Meadow Vole cannot be called an albino.

\section{LEPIDOPTERA COLLECTED IN THE PERRY RIVER REGION, NORTHWEST TERRITORIES}

\author{
by Spencer G. Sealy, Department of Zoology, U.B.C., Vancouver
}

During the period July 8 to August 12, 1965, the writer assisted J. P. Ryder in Canadian Wildlife Service studies of Ross' Goose in the Perry River region, Northwest Territories $67^{\prime} 42^{\prime \prime} \mathrm{N}, 102^{\prime}$ 15" W). During this time a collection of Lepidoptera was made, the results being presented here. The specimens, deposited in the
Canadian National Collection of Insects (Lot No. 66-59), were identified through the courtesy of Dr. J. E. H. Martin by taxonomists D. F. Hardwick, G. Lewis, and W. C. McGuffin of the Canada Department of Agriculture, Entomology Research Institute in Ottawa.

(Continued on page 202) 
LEPIDOPTERA (Cont. from p. 196)

For a detailed description of the climate and topography of the Perry River area the reader is referred to Hanson, Queneau and Scott (1956). The weather during the period in which this collection was made was generally sunny and clear during the day with maximum temperatures around $60^{\circ} \mathrm{F}$. The entire collection was made in close proximity to the Perry River from its mouth to about 15 miles inland.

\section{LIST OF SPECIES}

Melissa Arctic, Oeneis melissa Fabr. -one male and three females. One specimen, a male, of $O . m$. semplei Gibs. was also collected.

Ross' Alpine, Erebia rossii Curt. one specimen, a male. This species was also recorded by Hanson, et al (1956).

ArCtic Fritillary, Boloria chariclea Schneid-one specimen, a male. This species was also recorded by Hanson et al (1956).

Polaris Frittlary, Boloria polaris Bdv. - three males.

FrigGa, Boloria frigga Thun. - two males and two females.

Dingy Fritillary, Boloria improba Butl. - two males.

Hecla Orange, Colias hecla Lef. two males and four females.

Nastes Sulphur, Colias Nastes Bdv. - one specimen, a female.

Aspilates orciferarius orciferarius Wlk. - two males and one female.

Dasyuris polata Dup. - one male.

RICHARDSON'S ANARTA, Anarta richardsonii Curt. - one female.

Sympistis labradorius Staud. - one female.

The scientific names used in this list follow McDunnough (1938, 1939) and the vernacular names are taken from Holland $(1898,1904)$ and Klots (1960).

\section{LITERATURE CITED}

Hanson, H. C., P. Queneau and P. Scott. 1956. The geography, birds and mammals of the Perry River region. Arct. Instit. of N. Am. Spec. Publ. No. 3. 92pp.

Holland, W. J. 1898. The butterfly book. William Briggs, Toronto. $\mathrm{xx}+382 \mathrm{pp}$.
Holland, W. J. 1904. The moth book. William Briggs, Toronto. xxiv. $+479 \mathrm{pp}$.

Klots, A. B. 1960. A field guide to the butterflies. Houghton Mifflin Co., Boston. xvi+ $349 \mathrm{pp}$.

McDunnough, J. 1938. Check list of the Lepidoptera of Canada and the United States of America Part 1. Macrolepidoptera. 272pp.

McDunnough, J. 1939. Check list of the Lepidoptera of Canada and the United States of America. Part 2. Microlepidoptera. 169pp.

\section{CORRECTION}

In the June, 1966, Blue Jay in the article on the Gray Jay by Joyce L. Smith editorial manipulation has introduced some error in the first paragraph on page 68. Riding Mountain National Park and the Spruce Woods Forest Reserve are the boreal forest sections within the parkland of southwestern Manitoba, but Agassiz, Sandilands, Whiteshell, and Northwest Angle Forest Reserves are part of the continuous boreal forest in eastern Manitoba.-The Editor.

\section{APOLOGIES!}

In the last issue of the Blue Jay (Vol. $24: 155$ ) we failed to give credit for the note on the impaled bat. This note was submitted by $\mathrm{Mr}$. A. J. Hruska, Gerald, Saskatchewan. Please accept our apologies for this omission. -The Editor.

\section{"BANDING" INSECTS}

Greetings to all Blue Jay members. The September Newsletter of the Federation of Ontario Naturalists asks us to watch for "banded" dragonflies. My wife and I have helped Dr. Urquhart of Toronto with his study of Monarch Butterfly migration for about 15 years.-Frank J. Throm, Overland Park, Kansas.

\section{MOCKINGBIRD AT BLADWORTH}

On June 29, 1966, I was looking at the weed situation in the crop when a slender bird with a long tail appeared from the east. It landed on a willow for a few seconds and then continued west. It had very noticeable white wing and tail patches and the body was greyish. I am sure it was a Mockingbird. - Lawrence Beckie, Bladworth. 